\title{
PROTECTIVE EFFECTS OF DIETARY FIBRE AGAINST MANGANESE-INDUCED NEUROBEHAVIORAL ABERRATIONS IN RATS
}

\author{
Xiu-Quan SHI ${ }^{1}$, Wei YAN ${ }^{2}$, Ke-Yue WANG ${ }^{2}$, Qi-Yuan FAN ${ }^{2}$, and Yan ZOU ${ }^{1}$ \\ Department of Epidemiology and Health Statistics ${ }^{1}$, Department of Health Toxicology ${ }^{2}$, School of Public Health, Zunyi \\ Medical College, Zunyi, China \\ Received in September 2011 \\ CrossChecked in September 2011 \\ Accepted in June 2012
}

\begin{abstract}
We tested the hypothesis that dietary fibre (DF) has protective effects against manganese (Mn)-induced neurotoxicity. Forty-eight one-month old Sprague-Dawley rats were randomly divided into six groups: control, $16 \% \mathrm{DF}$, Mn (50 mg kg-1 body weight), Mn+ $4 \% \mathrm{DF}, \mathrm{Mn}+8 \% \mathrm{DF}$, and Mn+ $16 \% \mathrm{DF}$. After oral administration of $\mathrm{Mn}\left(\right.$ as $\mathrm{MnCl}_{2}$ ) by intragastric tube during one month, we determined $\mathrm{Mn}$ concentrations in the blood, liver, cerebral cortex, and stool and tested neurobehavioral functions. Administration of Mn was associated with increased Mn concentration in the blood, liver, and cerebral cortex and increased Mn excretion in the stool. Aberrations in neurobehavioral performance included increases in escape latency and number of errors and decrease in step-down latency. Irrespective of the applied dose, the addition of DF in forage decreased tissue Mn concentrations and increased Mn excretion rate in the stool by $20 \%$ to $35 \%$. All neurobehavioral aberrations were also improved. Our findings show that oral exposure to Mn may cause neurobehavioral abnormalities in adult rats that could be efficiently alleviated by concomitant supplementation of DF in animal feed.
\end{abstract}

KEY WORDS: escape latency, neurobehavioral test performance, number of errors, oral exposure, stepdown latency

Manganese (Mn) is distributed widely in the air and water in a number of chemical and physical forms. It is very active and could be in 11 oxidation states in the geological environment. Among those, $\mathrm{Mn}^{2+}$ and $\mathrm{Mn}^{3+}$ are especially important for biological tissues (1). Generally, $\mathrm{Mn}^{2+}$ is more stable than $\mathrm{Mn}^{3+}$.

Manganese is an essential trace nutrient in all forms of life. It is necessary for normal functioning of a variety of physiological processes that include protein, amino acid, carbohydrate, and lipid metabolism and can be found in various biological tissues. Manganese also plays an essential role in regulating bone and connective tissue growth, cellular energy, immune function, and blood clotting. As a cofactor for glial- specific glutamine synthetase, pyruvate carboxylase, superoxide dismutase (SOD), and other enzymes in the brain, Mn is involved in neurotransmitter synthesis and metabolism $(2,3)$.

For many years, however Mn has also been known to exert neurotoxic effects. It can enter the brain tissue by crossing the blood-brain barrier via several routes. Excessive chronic exposure to Mn can cause progressive and persistent neurodegenerative damage associated with numerous psychiatric and motor disturbances, resembling the idiopathic Parkinson's disease. The syndrome includes tremor, postural instability, bradykinesia, gait disturbance, rigidity, ataxia, and even cognitive deficits $(1,4)$. Among these 
symptoms, cognitive deficits such as spatial working memory, reference memory, and learning capacity disorders have received less attention than motor function disorders. Josephs et al. (4) reported reduced learning capacity in occupationally Mn-exposed welders, and Schneider et al. (5) found that monkeys developed subtle deficits in spatial working memory after exposure to $\mathrm{MnSO}_{4}$.

Exposure to airborne Mn pollution occurs through fumes at the workplace and outdoors. Epidemiological studies in occupationally exposed workers showed a significant positive correlation between lifetime cumulative or integrated $\mathrm{Mn}$ exposure and neurological dysfunction (1, 6-7). Chronic exposure to excessive Mn levels can lead to a variety of psychiatric and motor disturbances, so-called manganism. It can occur due to occupational exposure during $\mathrm{Mn}$ dioxide mining and grinding, ferri-manganese smelting and welding, dry-battery-factory production, Mn oxide production, and $\mathrm{Mn}$ salt production (7). Symptoms of manganism include cephalalgia, fatigue, sleep disturbances, sialorrhoea, adynamia, muscular pain and hypertonia, mask-like face, gait changes, reduced coordination, hallucinations, and mental irritability. Among these symptoms, cognitive deficits including disturbance of learning and memory are particularly dramatic. Bowler et al. (8) explored the relationship between Mn exposure and learning and memory in bridge welders. Bouchard et al. (9) conducted a followup study of alloy workers and concluded that $\mathrm{Mn}$ cumulative exposure could lead to learning and memory deficits. In spite of the criticism due to certain biases pointed out in the above mentioned reports, the fact remains that Bowler et al. (8) confirmed the correlation between abnormal neuropsychological findings and $\mathrm{Mn}$ exposure in welders in a dose-related manner.

In recent years, $\mathrm{Mn}$ in the form of 3-hydroxymethyl cyclopentadienyl manganese (MMT) has replaced tetraethyl-lead in gasoline as an antiknock agent. This application of $\mathrm{Mn}$ has led to more serious ambient air pollution (10).

Manganese can be absorbed through the respiratory tract by inhalation; 'but most of the absorption is through the digestive tract, especially in chronic exposure. So far, studies of the intake and neurotoxicity of Mn have principally focused on its absorption through the respiratory tract, and less attention was paid to the absorption through the gastrointestinal tract, especially in population-based studies.
Dietary fibres (DF) are present in many plants and play an important role in the maintenance of human health (11-13). A copious intake of DF reduces the risk of numerous health disorders and diseases, such as hypertension, cardiovascular diseases, and colorectal cancer $(11,13,14)$. Furthermore, DF consumption may improve serum lipid and cholesterol concentrations (15), blood glucose in diabetes (11), and possibly even the immune function. Sherry et al. (16) reported that soluble DF had an ability to alleviate endotoxin-induced sickness behaviour through the up-regulation of interleukin-4 (IL-4) and lymphocyte $\mathrm{T}$ helper (Th2) cell polarisation. All these reports identify the benefits of DF and suggest that DF can be considered the "seventh nutrient".

One of DF's benefits is that it can influence the absorption of metals such as cadmium (Cd), lead (Pb), mercury $(\mathrm{Hg})$, and copper $(\mathrm{Cu})$. More than twenty years ago, Drews et al. (17) reported the effect of DF on $\mathrm{Cu}$, zinc $(\mathrm{Zn})$, and magnesium $(\mathrm{Mg})$ utilisation in adolescent boys. Recently, Yang et al. (18) reported that chlorella (whose main compound is DF) intake had effects on $\mathrm{Cd}^{2+}, \mathrm{Pb}^{2+}, \mathrm{Hg}^{2+}$ absorption; Shim et al. (19) reported the effects of chlorella intake on $\mathrm{Cd}$ metabolism in rats; and Ou et al. (20) found that wheat bran DF effectively bound three tested metal ions and provided protection against metal' toxicity. In the most recent paper, Callegaro et al. (21) reported that cereal bran supplements (a type of food from Brazil with DF as its main component) reduced the effects of $\mathrm{Cd}$ at lower concentrations in young rats, but was inefficient against higher $\mathrm{Cd}$ concentrations.

To sum up, literature data published so far suggest that DF could change the absorption of several metal ions and/or accelerate their excretion. However, reports on DF interaction with $\mathrm{Mn}$ ions are rare. This is why we wanted to test the hypothesis that DF had protective effects against Mn neurotoxicity in an animal model in vivo by exposing adult rats to different Mn concentrations with or without DF and testing their neurobehavioral performance.

\section{MATERIALS AND METHODS}

\section{Chemicals}

Manganese chloride $\left(\mathrm{MnCl}_{2}\right.$, purchased from Chemical Reagent Company of Chinese Medicine Group, Shanghai, China) was used as test chemical. Soybean DF (purchased from Yunhai International 
Trade Limited Company (Tianjin, China) is composed in main portion of total dietary fibres (dry basis $\geq 65 \%$ ); other ingredients are moisture $(\leq 8 \%)$, ash $(\leq 7 \%)$, protein $(\leq 20 \%)$, and fat $(\leq 1 \%)$. No toxic substance was detected (such as other heavy metals). Its quality was controlled by the Bureau of Product Quality Supervision of the Shandong Province, China. Nitric acid (purchased from Development Center of Kemio Chemical Reagent, Tianjin, China) was chromatographic pure grade.

\section{Animals}

Forty-eight three-week-old male Sprague-Dawley rats were used in the experiment (purchased from Laboratory Animal Centre of Third Military Medical University). The rats were fed with full grain, had free access to forage and tap water, and were kept under controlled indoor temperature of $(20 \pm 2)^{\circ} \mathrm{C}$, with the light and dark cycle exchanging every 12 hours. Rats were housed in plastic cages $(45 \mathrm{~cm} \times 32 \mathrm{~cm} \times 19 \mathrm{~cm})$ with four rats per cage. The cages were supplied with sawdust as bedding and a metal grid on top. Animals' general health during the experiment was checked by measuring body weight at the beginning and the termination of the experiment.

\section{Experimental design}

After the adaptation period of one week, the rats were randomised into six groups of eight, as follows: the control group, $16 \% \mathrm{DF}, \mathrm{Mn}, \mathrm{Mn}+4 \% \mathrm{DF}$, $\mathrm{Mn}+8 \% \mathrm{DF}$, and $\mathrm{Mn}+16 \% \mathrm{DF}$. Manganese (as $\mathrm{MnCl}_{2}$ ) was given in a dose of $50 \mathrm{mg} \mathrm{kg}^{-1}$ body weight by gavage once a day. Soybean DF was mixed with rat forage in the following percentages: $4 \%, 8 \%$, and $16 \%$. This dose was calculated using a simple formula: soybean DF weight was divided by total forage weight and multiplied with 100 . The control and the $16 \%$ DF group received physiological saline in the dose of $10 \mathrm{~mL} \mathrm{~kg}^{-1}$ body weight using the same procedure as for $\mathrm{Mn}$. All animals were treated for one month.

The experimental protocol was reviewed and approved by the Ethics Review Committee for Laboratory Animal Research at the Affiliated Hospital of Zunyi Medical College.

\section{Neurobehavioral tests}

Morris water maze test was performed on all rats (22) after the one-month treatment. The water maze was a grey-circular tub filled with water at $25^{\circ} \mathrm{C}$. The diameter of the water maze was $120 \mathrm{~cm}$ and total depth $35 \mathrm{~cm}$. Water was filled up to $15 \mathrm{~cm}$ from the brim. In the centre of the northeast quadrant of the water maze at the depth of $2 \mathrm{~cm}$ under the water surface, there was a black platform with a diameter of $12 \mathrm{~cm}$. In order to hide the platform, water was stained with milk. The pool was always in the same position and the experiment carried out by the same people. In the locating navigation experiment, rats were placed at one of the four starting points (northeast, southeast, southwest, and northwest) facing the wall of the pool to enter the water, and the same rats started from the same points for the five consecutive test days. If the rats failed to get to the platform in $120 \mathrm{~s}$ (escape latency), they were guided to it, stayed there for $30 \mathrm{~s}$, and their escape latency counted as $120 \mathrm{~s}$. At the end of every trial, the rats were towelled, fan dried, and put back to their cages for a 15-minute rest, then they were re-tested and the tests were run twice a day. All results were recorded automatically by the computer. Here we report average time.

For the step-down test the rats were put onto a floor grid inside a rectangular box for $3 \mathrm{~min}$ to adapt to the environment and then shocked with $36 \mathrm{~V}$ alternating current. A normal reaction was to jumping onto a platform above the floor grid to escape the shock. After a while, the rats would return step back down the floor grid, and most repeated this action twice or even several times. The training lasted $5 \mathrm{~min}$. After $24 \mathrm{~h}$, the test was repeated and the latency of the first time to step down from the platform (step-down latency) and the number of errors within 3 min number of errors) recorded for every rat. If a rat did not step down onto the grid platform within $3 \mathrm{~min}$, the number of errors was counted as 0 , and the step-down latency was counted as $180 \mathrm{~s}$.

\section{Manganese tissue analysis}

Twenty-four-hour stool samples were collected using metabolic cages $24 \mathrm{~h}$ before the rats were decapitated under diethyl ether and dissected. Blood was collected after decapitation, and liver and cerebral cortex dissected for Mn determination.

One gram of liver, $0.2 \mathrm{~g}$ of cerebral cortex, and 0.2 $\mathrm{g}$ of wet stool were placed into a crucible and baked at $100{ }^{\circ} \mathrm{C}$ for $16 \mathrm{~h}$. Blood $(0.2 \mathrm{~mL})$ was taken by suction and digested in a microwave after evaporation on an electric hot plate. Then the samples were dissolved with $10 \mathrm{~mL}$ of nitric acid for the final tests. Blood and cerebral cortex Mn level was determined by graphite furnace atomic absorption spectrometry 
(AAS, Varian Inc., USA); and stool and liver Mn level by flame AAS. Mn excretion over $24 \mathrm{~h}$ was computed using the following equation:

Mn-excretion rate $(\%)=24-\mathrm{h} \mathrm{Mn}$ in the stool / 24-h Mn by gavage administration $\times 100$

\section{Essential micronutrient tissue analysis}

Blood, liver, and cerebral cortex $\mathrm{Zn}, \mathrm{Cu}$, and $\mathrm{Fe}$ concentrations were determined using an automatic biochemical analyser (AU2700, OLMPUS Inc., Japan).

\section{Statistical analysis}

The results are presented as mean \pm standard deviation (SD). All data were analysed using the analysis of variance (ANOVA), and post hoc LSD tests were used for multiple comparisons. Dosedependency was tested with factorial ANOVA using linear trend testing. All tests were two-tailed. Difference at the level of $P<0.05$ was considered statistically significant. We used the Statistical Package for Solution and Services software (version 18.0; SPSS Institute, California, USA).

\section{RESULTS}

At the beginning of the experiment, average rat weight per group was about $180 \mathrm{~g}$. After one-month of treatment, their body weight increased about $60 \mathrm{~g}$ in average in all groups. The groups did not differ in total forage intake and body weight gain.

\section{Escape latency}

The overall ANOVA test showed a significant difference in escape latency between all groups
( $F=36.6, P<0.001)$. Multiple comparisons showed a significant increase in escape latency in the Mn group in respect to control for test days 2 through 5 . The $16 \%$ DF group did not differ from control. Over the same test days, the escape latency in Mn+DF-treated groups was significantly lower than in the $\mathrm{Mn}$ group and the lowering trend correlated with increasing DF percentage (Table 1, first five columns). It also dropped with test days 2 to 5 .

\section{Step-down latency and number of errors}

Compared to control, step-down latency significantly dropped in the Mn group and the average number of errors significantly increased. No significant difference was found between control and the $16 \%$ DF group. Latency also improved in the $\mathrm{Mn}+8 \% \mathrm{DF}$ and $\mathrm{Mn}+16 \% \mathrm{DF}$ groups compared to the Mn group and reached control values. Adding DF to the forage significantly decreased the number of errors and reached control value in all three $\mathrm{Mn}+\mathrm{DF}$ groups (Table 1, last two columns).

\section{Tissue Mn concentrations}

Compared to control, blood, liver, and cerebral cortex $\mathrm{Mn}$ concentrations significantly increased in the Mn group, whereas blood, liver, cerebral cortex, and stool Mn was comparable between control and the $16 \%$ DF group. The addition of DF, significantly lowered blood, liver, and cerebral cortex $\mathrm{Mn}$ concentrations in all three $\mathrm{Mn}+\mathrm{DF}$ groups, but they remained higher than control, save for cerebral cortex in the $\mathrm{Mn}+16 \% \mathrm{DF}$ group. Mn excretion was significantly higher in all $\mathrm{Mn}+\mathrm{DF}$ groups (Table 2) and showed a linear correlation with increasing DF percentage. A similar linear correlation was found for $\mathrm{Mn}$ concentrations, which dropped in the liver and

Table 1 Effects of oral exposure to manganese $\left(50 \mathrm{mg} \mathrm{kg}^{-1}\right.$ of body weight in the form of $\mathrm{MnCl}$, over one month) alone and in combination with increasing concentrations of dietary fibres $(4 \% \mathrm{DF}, 8 \% \mathrm{DF}, 16 \% \mathrm{DF})$ on neurobehavioral tests: escape latency, step-down latency, and number of errors in rats

\begin{tabular}{|c|c|c|c|c|c|c|c|}
\hline \multirow{2}{*}{ Group } & \multicolumn{5}{|c|}{ Escape latency in Morris Maze Test(s) } & \multirow{2}{*}{$\begin{array}{l}\text { Step-down } \\
\text { latency(s) }\end{array}$} & \multirow{2}{*}{$\begin{array}{l}\text { Number } \\
\text { of errors }\end{array}$} \\
\hline & $1^{\text {st }}$ Day & $2^{\text {nd }}$ Day & $3^{\text {rd }}$ Day & $4^{\text {th }}$ Day & $5^{\text {th }}$ Day & & \\
\hline & $060=7$ & 001500 & $7.2 \pm 2.93^{\mathrm{a}}$ & $9.3 \pm 4.76$ & 751226 & & $1.13 \pm 0.640^{\mathrm{a}}$ \\
\hline & & & & & & & \\
\hline S & 4 & $74.7 \pm 1$ & $46.1 \pm 9.22^{b}$ & $50.4 \pm 17$ & $31.4 \pm 4$ & 133 & $2.17 \pm 0.753^{\mathrm{b}}$ \\
\hline & 5 & $48.5 \pm 9.60^{c}$ & $35.2 \pm 6.70^{c}$ & $31.6 \pm 4.74^{\mathrm{c}}$ & $33.7 \pm 5$. & 135 & $1.88 \pm 0.641^{\mathrm{a}}$ \\
\hline & & $41.1 \pm$ & $27.5 \pm 3.6$ & $23.0 \pm 3.46^{\mathrm{ac}}$ & $17.9 \pm 2$ & $157=$ & $0.750 \pm 0.886^{\mathrm{a}}$ \\
\hline $\mathrm{Mn}+16 \% \mathrm{DF}$ & $103 \pm 9.53^{\mathrm{a}}$ & $40.3 \pm 4.00^{\text {ac\# }}$ & $27.0 \pm 4.56^{\mathrm{ac} \#}$ & $20.1 \pm 4.65^{\mathrm{ac \#}}$ & $20.9 \pm 4.72^{\mathrm{ct}}$ & $162 \pm 12.3^{\text {a\# }}$ & $0.875 \pm 0.641^{\mathrm{a}}$ \\
\hline
\end{tabular}

Different superscript letters in each column denote significant difference $(P<0.05)$ between respective groups.

"Significant linear trend $(P<0.05)$ with higher DF levels. 
cerebral cortex and rose in the stool as DF levels increased $(P<0.05)$ (Table 2).

\section{Micronutrients tissue concentrations}

No difference in any of the observed micronutrient $(\mathrm{Zn}, \mathrm{Cu}$, and $\mathrm{Fe}$ ) in blood, liver, or cerebral cortex concentration was found between the groups (Table 3).

\section{DISCUSSION}

Neurobehavioral changes induced by manganese

Beside factors related to the host organism, chemical forms may influence Mn absorption, distribution, and toxicity (23). Our choice of $\mathrm{MnCl}_{2}$ was based on following reports. Reaney et al. (24) reported that $\mathrm{Mn}^{2+}$ and $\mathrm{Mn}^{3+}$ differed in toxic properties and Gunter et al. (25) reported $\mathrm{Mn}^{3+}$ could not be positively identified in the mitochondria of neuroteratocarcinoma ( $\mathrm{NT}_{2}$ ) cells, liver, brain, or heart. These findings suggest that $\mathrm{Mn}^{2+}$ is the toxic form for humans.

Although $\mathrm{Mn}$ is essential for normal brain development and function, it could be harmful to the immune, reproductive, and other systems and has a neurotoxic potential at high levels (1-3). Learning and memory are two most important facets of cognition and thus indispensable for the research of cerebral functions. Regarded as a standard procedure, Morris water maze test is extensively used to evaluate memory and spatial learning of rodents $(22,26)$. Step-down test is another common method to study learning and

Table 2 Effects of oral exposure to manganese $\left(50 \mathrm{mg} \mathrm{kg}^{-1}\right.$ body weight in the form of $\mathrm{MnCl}$, over one month) alone and in combination with increasing concentrations of dietary fibres $(4 \% \mathrm{DF}, 8 \% \mathrm{DF}, 16 \% \mathrm{DF})$ on blood, liver, cerebral cortex, and stool levels in rats

\begin{tabular}{|c|c|c|c|c|c|}
\hline \multirow[b]{2}{*}{ Group } & \multicolumn{4}{|c|}{ Mn levels } & \multirow{2}{*}{$\begin{array}{c}\text { Mn-excretion } \\
\text { rate }^{*} \%\end{array}$} \\
\hline & $\operatorname{Blood} / \mu \mathrm{g} \mathrm{mL} L^{-1}$ & Liver $/ \mu \mathrm{g} \mathrm{g}^{-1}$ & $\begin{array}{c}\text { Cerebral } \\
\text { cortex / } \mu \mathrm{g} \mathrm{g}^{-1}\end{array}$ & Stool / mg g-1 & \\
\hline Control & $0.243 \pm 0.0357^{\mathrm{a}}$ & $1.78 \pm 0.333^{\mathrm{a}}$ & $1.37 \pm 0.219^{\mathrm{a}}$ & $0.330 \pm 0.148^{\mathrm{a}}$ & - \\
\hline $16 \% \mathrm{DF}$ & $0.245 \pm 0.0416^{\mathrm{a}}$ & $2.03 \pm 0.260^{\mathrm{a}}$ & $1.42 \pm 0.221^{\mathrm{a}}$ & $0.280 \pm 0.0894^{\mathrm{a}}$ & - \\
\hline $\mathrm{Mn}$ & $0.483 \pm 0.0665^{\mathrm{b}}$ & $3.22 \pm 0.248^{b}$ & $3.59 \pm 0.441^{\mathrm{b}}$ & $2.49 \pm 0.629^{b}$ & $20.9 \pm 5.16^{\mathrm{a}}$ \\
\hline $\mathrm{Mn}+4 \% \mathrm{DF}$ & $0.371 \pm 0.0789^{c}$ & $2.70 \pm 0.347^{\mathrm{c}}$ & $2.57 \pm 0.247^{\mathrm{c}}$ & $2.91 \pm 0.726^{b}$ & $26.2 \pm 7.59^{b}$ \\
\hline $\mathrm{Mn}+8 \% \mathrm{DF}$ & $0.375 \pm 0.0460^{c}$ & $2.54 \pm 0.183^{\mathrm{c}}$ & $2.24 \pm 0.178^{\mathrm{c}}$ & $3.19 \pm 0.557^{\mathrm{c}}$ & $28.5 \pm 5.78^{b}$ \\
\hline $\mathrm{Mn}+16 \% \mathrm{DF}$ & $0.351 \pm 0.0548^{c}$ & $2.73 \pm 0.192^{\mathrm{c \#}}$ & $1.62 \pm 0.132^{\mathrm{ac} \#}$ & $3.31 \pm 0.735^{\mathrm{c \#}}$ & $29.4 \pm 5.57^{\mathrm{b} \S}$ \\
\hline
\end{tabular}

Different superscript letters in each column denote significant difference $(P<0.05)$ between respective groups.

"Mn-excretion rate /\% = 24- $h \mathrm{Mn}$ in the stool / 24- $h$ Mn by gavage administration $\times 100$.

\#Significant linear trend $(P<0.05)$ with higher $D F$ levels.

Borderline significant linear trend $(P=0.06)$ with higher $D F$ levels.

Table 3 Effects of oral exposure to manganese (50 mg kg-1 body weight in the form of $\mathrm{MnCl}$, over one month) alone and in combination with increasing doses of dietary fibres $(4 \% \mathrm{DF}, 8 \% \mathrm{DF}, 16 \% \mathrm{DF})$ on blood, liver, and cerebral cortex micronutrient levels in rats

\begin{tabular}{|c|c|c|c|c|c|c|c|c|c|}
\hline \multirow[t]{2}{*}{ Group } & \multicolumn{3}{|c|}{ Concentration in blood $/ \mu \mathrm{mol} \mathrm{L} \mathrm{L}^{-1}$} & \multicolumn{3}{|c|}{ Mass fraction in liver / $\mu \mathrm{g} \mathrm{g}^{-1}$} & \multicolumn{3}{|c|}{$\begin{array}{l}\text { Mass fraction in cerebral } \\
\text { cortex } / \mu \mathrm{g} \mathrm{g}^{-1}\end{array}$} \\
\hline & $\mathrm{Zn}$ & $\mathrm{Cu}$ & $\mathrm{Fe}$ & $\mathrm{Zn}$ & $\mathrm{Cu}$ & $\mathrm{Fe}$ & $\mathrm{Zn}$ & $\mathrm{Cu}$ & $\mathrm{Fe}$ \\
\hline Control & $10.7 \pm 1.32$ & $20.1 \pm 4.97$ & $51.2 \pm 4.51$ & $57.3 \pm 6.85$ & $1.83 \pm 0.358$ & $130 \pm 21.1$ & $42.5 \pm 3.06$ & $0.652 \pm 0.0190$ & $45.9 \pm 6.66$ \\
\hline $16 \% \mathrm{DF}$ & $11.0 \pm 2.36$ & $22.4 \pm 5.64$ & $49.6 \pm 8.14$ & $57.2 \pm 4.65$ & $1.78 \pm 0.218$ & $131 \pm 18.9$ & $42.9 \pm 4.93$ & $0.634 \pm 0.0279$ & $44.8 \pm 6.82$ \\
\hline $\mathrm{Mn}$ & $9.47 \pm 2.38$ & $20.3 \pm 2.95$ & $43.5 \pm 7.61$ & $52.5 \pm 3.94$ & $1.69 \pm 0.221$ & $116 \pm 18.5$ & $39.4 \pm 6.08$ & $0.613 \pm 0.0646$ & $43.3 \pm 7.94$ \\
\hline $\mathrm{Mn}+4 \% \mathrm{DF}$ & $11.3 \pm 1.38$ & $24.1 \pm 4.39$ & $44.5 \pm 4.72$ & $56.9 \pm 4.27$ & $1.70 \pm 0.441$ & $121 \pm 11.9$ & $41.2 \pm 4.21$ & $0.642 \pm 0.0301$ & $43.2 \pm 3.91$ \\
\hline $\mathrm{Mn}+8 \% \mathrm{DF}$ & $10.7 \pm 0.77$ & $22.8 \pm 2.62$ & $54.1 \pm 14.4$ & $54.6 \pm 4.14$ & $1.78 \pm 0.410$ & $123 \pm 18.6$ & $43.9 \pm 5.07$ & $0.654 \pm 0.0189$ & $43.8 \pm 4.84$ \\
\hline $\mathrm{Mn}+16 \% \mathrm{DF}$ & $10.1 \pm 2.15$ & $23.1 \pm 6.30$ & $53.9 \pm 13.7$ & $55.2 \pm 6.20$ & $1.71 \pm 0.409$ & $131 \pm 17.1$ & $43.7 \pm 6.55$ & $0.667 \pm 0.0706$ & $44.2 \pm 6.9$ \\
\hline
\end{tabular}

No statistical difference was determined between the study groups. 
memory. In this study, we evaluated both learning and memory and found that oral Mn exposure significantly increased the escape latency, as the exposed rats needed more time to find the platform beneath the water surface. Shorter latency and more errors in the stepdown test also confirmed that exposure to Mn could affect learning and memory. Our findings corroborate the findings of earlier studies, which showed that exposure to Mn caused permanent aberrations in spontaneous behaviour, learning, and memory functions in mammals, including humans (1).

\section{Protective effects of dietary fibres against Mn neurotoxicity}

The primary objective of our study was to assess the protective effects of DF against Mn neurotoxicity. We found that $\mathrm{DF}$ antagonised $\mathrm{Mn}$ in rats co-exposed to $4 \%, 8 \%$, and $16 \%$ DF and $50 \mathrm{mg} \mathrm{kg}^{-1}$ body weight $\mathrm{Mn}$, as their escape latency significantly shortened compared to rats exposed to Mn alone. However, only in groups that supplemented with $8 \% \mathrm{DF}$ and $16 \%$ DF was escape latency similar to control. Moreover, rats supplemented with DF showed a significantly lower step-down latency and error proneness than rats exposed to Mn alone. These results suggest that DF can provide significant protection against $\mathrm{Mn}$-induced neurotoxic effects, especially at $8 \%$ and $16 \%$ concentrations. These findings are consistent with the protective effects of DF against other heavy metals $(\mathrm{Cd}, \mathrm{Pb}, \mathrm{Hg}, \mathrm{Cu}$ and $\mathrm{Mg}$ ) (17-20).

However, our results were partly differ from those of Callegaro et al. (27), who reported that high-level DF supplements could reduce the absorption of calcium $(\mathrm{Ca})$, phosphorus $(\mathrm{P}), \mathrm{Mg}$, and $\mathrm{Cu}$, whereas $\mathrm{Mn}$ absorption increased in spite of high DF supplementation. The main reason for this difference may be that our DF was extracted from soybean and was metal free whereas in the study by Callegaro et al. it was a mixture with a high content of various minerals that affect the binding capacity of DF.

Our findings on the Mn excretion rate suggest that DF can facilitate Mn excretion and thus reduce its accumulation in tissues such as blood, liver, and cerebral cortex. The protective effect of DF on the neurotoxicity of Mn appears even more valuable if we take into account that it did not change micronutrient levels.

Manganism treatment is still in want of successful methods (1). Our study suggests that DF can alleviate manganism symptoms and offers a new approach to its treatment and prevention.

\section{Acknowledgements}

The authors wish to thank Jie Liu (Kansas State University, USA) for his critical review and scientific editing of this manuscript. This study was supported by a grant of Special-Talents-Research Program of Guizhou, China (TZJF-2008-62) and a grant of the Science and Technology Development Program of Zunyi, China (ZY-2009-3).

\section{REFERENCES}

1. Aschner M, Guilarte TR, Schneider JS, Zheng W. Manganese: recent advances in understanding its transport and neurotoxicity. Toxicol Appl Pharmacol 2007;221:131-47.

2. Santamaria AB. Manganese exposure, essentiality and toxicity. Indian J Med Res 2008;128:484-500.

3. Yokel RA. Manganese flux across the blood-brain barrier. Neuromol Med 2009;11:297-310.

4. Josephs KA, Ahlskog JE, Klos KJ, Fealey RD, Trenerry MR, Cowl CT. Neurologic manifestations in welders with pallidal MRI T1 hyperintensity. Neurology 2005;64:2033-9.

5. Schneider JS, Decamp E, Koser AJ, Fritz S, Gonczi H, Syversen T, Guilarte TR. Effects of chronic manganese exposure on cognitive and motor functioning in non-human primates. Brain Res 2006;1118:222-31.

6. Lucchini R, Apostoli P, Perrone C, Placidi D, Albini E, Migliorati P, Mergler D, Sassine MP, Palmi S, Alessio L. Long-term exposure to "low levels" of manganese oxides and neurofunctional changes in ferroalloy workers. Neurotoxicol 1999;20:287-97.

7. Ono K, Komai K, Yamada M. Myoclonic involuntary movement associated with chronic manganese poisoning. J Neurol Sci 2002;199:93-6.

8. Bowler RM, Roels HA, Nakagawa S, Drezgic M, Diamond E, Park R, Koller W, Bowler RP, Mergler D, Bouchard M, Smith D, Gwiazda R, Doty RL. Dose-effect relationships between manganese exposure and neurological, neuropsychological and pulmonary function in confined space bridge welders. Occup Environ Med 2007;64:16777.

9. Bouchard M, Mergler D, Baldwin ME, Panisset M. Manganese cumulative exposure and symptoms: A follow-up study of alloy workers. Neurotoxicology 2008;29:577-83.

10. Finkelstein MM, Jerrett M. A study of the relationships between Parkinson's disease and markers of traffic-derived and environmental manganese air pollution in two Canadian cities. Environ Res 2007;104:420-32.

11. Anderson JW, Baird P, Davis RH Jr, Ferreri S, Knudtson M, Koraym A, Waters V, Williams CL. Health benefits of dietary fiber. Nutr Rev 2009;67:188-205.

12. Hillemeier C. An overview of the effects of dietary fiber on gastrointestinal transit. Pediatrics 1995;96:997-9.

13. Dahm CC, Keogh RH, Spencer EA, Greenwood DC, Key TJ, Fentiman IS, Shipley MJ, Brunner EJ, Cade JE, Burley VJ, Mishra G, Stephen AM, Kuh D, White IR, Luben R, Lentjes MA, Khaw KT, Rodwell Bingham SA. Dietary fiber and colorectal cancer risk: a nested case-control study using food diaries. J Natl Cancer Inst 2010;102:614-26. 
14. Eshak ES, Iso H, Date C, Kikuchi S, Watanabe Y, Wada Y, Wakai K, Tamakoshi A; JACC Study Group. Dietary fiber intake is associated with reduced risk of mortality from cardiovascular disease among Japanese men and women. J Nutr 2010;140:1445-53.

15. Ruottinen S, Lagström HK, Niinikoski H, Rönnemaa T, Saarinen M, Pahkala KA, Hakanen M, Viikari JS, Simell O. Dietary fiber does not displace energy but is associated with decreased serum cholesterol concentrations in healthy children. Am J Clin Nutr 2010;91:651-61.

16. Sherry CL, Kim SS, Dilger RN, Bauer LL, Moon ML, Tapping RI, Fahey GC Jr, Tappenden KA, Freund GG. Sickness behaviour induced by endotoxin can be mitigated by the dietary soluble fiber, pectin, through up-regulation of IL-4 and Th2 polarization. Brain Behav Immun 2010;24:63140.

17. Drews LM, Kies C, Fox HM. Effect of dietary fiber on copper, zinc, and magnesium utilization by adolescent boys. Am J Clin Nutr 1979;32:1893-7.

18. Yang XQ, Li LH, Qi B. [Adsorption of $\mathrm{Cd}^{2+}, \mathrm{Pb}^{2+}$ and $\mathrm{Hg}^{2+}$ by dietary fibers from four seaweeds, in Chinese]. Zhongguo Shui Chan Ke Xue 2007;14:132-8.

19. Shim JA, Son YA, Park JM, Kim MK. Effect of Chlorella intake on Cadmium metabolism in rats. Nutr Res Pract 2009;3:15-22.

20. Ou S, Gao K, Li Y. An in vitro study of wheat bran binding capacity for $\mathrm{Hg}$, Cd, and $\mathrm{Pb}$. JAgric Food Chem 1999;47:47147.

21. Callegaro MGK, Milbradt BG, Alves E, Diettrich T, Kemerich DM, Hausen BS, Duarte FA, Flores EM, Dressle
VL, Emanuelli T. Effect of wheat bran and flaxseed on cadmium effects and retention in rats. Hum Exp Toxicol 2011;30:981-91.

22. Morris R. Developments of a water-maze procedure for studying spatial learning in the rat. J Neurosci Methods 1984;11:47-60.

23. Yokel RA, Lasley SM, Dorman DC. The speciation of metals in mammals influences their toxicokinetics and toxicodynamics and therefore human health risk assessment. J Toxicol Environ Health B Crit Rev 2006;9:63-85.

24. Reaney SH, Kwik-Uribe CL, Smith DR. Manganese oxidation state and its implications for toxicity. Chem Res Toxicol 2002;15:1119-26.

25. Gunter KK, Aschner M, Miller LM, Eliseev R, Salter J, Anderson K, Gunter TE. Determining the oxidation states of manganese in NT2 cells and cultured astrocytes. Neurobiol Aging 2006;27:1816-26.

26. Kulig B, Alleva E, Bignami G, Cohn J, Cory-Slechta D, Landa V, O'donoghue J, Peakall D. Animal behavioral methods in neurotoxicity assessment: SGOMSEC joint report. Environ Health Perspect 1996;104(Suppl 2):193204

27. Callegaro MGK, Diettrich T, Alves E, Milbradtb BG, Denardinb CC, Silvac LP, Emanuelli T. Supplementation with fiber-rich multimixtures yields a higher dietary concentration and apparent absorption of minerals in rats. Nutr Res 2010;30:615-25. 


\section{Sažetak}

\section{ZAŠTITNO DJELOVANJE VLAKNASTOGA TKIVA U HRANI OD NEUROBIHEJVIORALNIH POREMEĆAJA UZROKOVANIH MANGANOM U ŠTAKORA}

U ovome je ispitivanju testirana hipoteza da vlaknasto tkivo u hrani (DF - od engl. dietary fibre) štiti od neurotoksičnoga djelovanja mangana $(\mathrm{Mn})$. Četrdeset i osam Sprague-Dawley štakora nasumce je raspoređeno u šest skupina: kontrolnu, skupinu koja je primala $16 \%$-tni udio vlaknastoga tkiva u hrani (DF $16 \%$ ), Mn (50 $\mathrm{mg} \mathrm{kg}^{-1}$ tjelesne težine), Mn+DF $4 \%$, Mn+DF $8 \%$ i Mn+DF $16 \%$. Nakon peroralne primjene $\mathrm{Mn}$ (u obliku $\mathrm{MnCl}_{2}$ ) kroz gastričnu cjevčicu u trajanju od mjesec dana, utvrdili smo koncentracije Mn u krvi, jetri, moždanoj kori i stolici te napravili pretrage neurobihejvioralnih funkcija. Primjena Mn bila je povezana s povišenom koncentracijom Mn u krvi, jetri i moždanoj kori te s povećanim uklanjanjem stolicom. Poremećaji neurobihejvioralne funkcije obuhvaćali su produljeno vrijeme bijega te veći broj pogrešaka i skraćeno vrijeme silaska s platforme. Bez obzira na primijenjenu dozu, dodavanje vlaknastoga tkiva u hranu dovelo je do pada koncentracija Mn i njegova povećanog uklanjanja stolicom za $20 \%$ do $35 \%$. Također su se popravili nalazi svih neurobihejvioralnih testova. Naši nalazi pokazuju da izlaganje Mn oralnim putom može dovesti do neurobihejvioralnih poremećaja u odraslih štakora, koji se mogu uspješno ublažiti istodobnim dodavanjem vlaknastoga tkiva u hranu.

KLJUČNE RIJEČI: broj pogrešaka, neurobihejvioralna funkcija, oralna izloženost, vrijeme bijega, vrijeme silaska s platforme

\section{CORRESPONDING AUTHOR:}

Ke-yue Wang

Department of Health Toxicology, School of Public Health, Zunyi Medical College

201 Dalian Road, Zunyi City, Guizhou Province, China Email: kywang@zmc.edu.cn 